\title{
MICROSTRUCTURE AND HARDENING BEHAVIOR OF ARGON-ION IRRADIATED STEELS 18Cr10NiTi AND 18Cr10NiTi-ODS
}

\author{
DIgor Kolodiya,*, (D) Oleksandr Kalchenkoa , DSergiy Karpova, (DVictor Voyevodin ${ }^{\mathrm{a}, \mathrm{b}}$, \\ (D)Mikhail Tikhonovskya, (D) Oleksii Velikodnyia, (D) Galyna Tolmachova ${ }^{a}$, \\ (D) Ruslan Vasilenko ${ }^{a}$, (D) Galyna Tolstolutska ${ }^{a}$ \\ ${ }^{a}$ National Science Center "Kharkov Institute of Physics and Technology", Kharkov, Ukraine \\ ${ }^{b}$ V.N. Karazin Kharkiv National University, Kharkov, Ukraine \\ *Corresponding Author: kolodiy@kipt.kharkov.ua \\ Received March 29, 2021; revised April 19, 2021; accepted April 20, 2021
}

\begin{abstract}
Microstructure and nanohardness evolution in $18 \mathrm{Cr} 10 \mathrm{NiTi}$ and $18 \mathrm{Cr} 10 \mathrm{NiTi}$-ODS steels after exposure to argon ion irradiation has been studied by combination of nanoindentation tests, XRD analysis, TEM and SEM observation. ODS-modified alloy was produced on the basis of conventional $18 \mathrm{Cr} 10 \mathrm{NiTi}$ austenitic steel by mechanical alloying of steel powder with $\mathrm{Y}(\mathrm{Zr})$-nanooxides followed by mechanical-thermal treatment. XRD analysis has showed no significant changes in the structure of 18Cr10NiTi steel after irradiation at room and elevated temperatures $(873 \mathrm{~K})$ and in ODS-steel after irradiation at $873 \mathrm{~K}$, whereas the evidences of domains refinement and microstrain appearance were revealed after irradiation of $18 \mathrm{Cr} 10 \mathrm{NiTi}-\mathrm{ODS}$ steel at room temperature (RT). Layer-by-layer TEM analysis was performed to investigate the microstructure of alloys along the damage profile. The higher displacement per atom (dpa) and Ar concentration clearly lead to increased cavities size and their number density in both steels. The swelling was estimated to be almost half for $18 \mathrm{Cr} 10 \mathrm{NiT}-\mathrm{ODS}$ (4.8\%) compared to $18 \mathrm{Cr} 10 \mathrm{NiTi}(9.4 \%)$ indicating improved swelling resistance of ODS-steel. The role of oxide/matrix interface as a sink for radiation-induced point defects and inert gas atoms is discussed. The fine dispersed oxide particles are considered as effective factor in suppressing of cavity coarsening and limiting defect clusters to small size. The hardness behavior was investigated in both non-irradiated and irradiated specimens and compared to those at RT and elevated temperature of irradiation. The hardness increase of unirradiated ODS-steel is associated mainly with grain refinement and yttrium oxides particles addition. The hardening of $18 \mathrm{Cr} 10 \mathrm{NiTi}-\mathrm{ODS}$ after Ar ion irradiation at RT was found to be much lower than 18Cr10NiTi. Black dots and dislocation loops are observed for both steels in the near-surface area; however, the main hardening effect is caused by the cavities. Oxide dispersion strengthened steel was found to be less susceptible to radiation hardening/embrittlement compared with a conventional austenitic steel.
\end{abstract}

KEYWORDS: austenitic steels, oxide particles, irradiation, microstructure, cavities, nanohardness, swelling, hardening, radiation resistance.

Structural materials of modern technical devices operate under extreme conditions (high temperatures, high mechanical stresses and high radiation doses). Exposure of materials under irradiation in nuclear reactors leads to changes in the crystalline structure at the atomic level due to the nucleation of various kinds of defects (such as voids, bubbles, dislocation loops and stacking faults). These defects can dramatically degrade the physical properties of reactor materials through swelling, irradiation hardening, embrittlement, irradiation creep, etc. [1].

Gen IV nuclear reactors concept imposes increased demands on structural materials. Therefore, the main challenge for reactor material science is the development of materials with high irradiation resistance that can operate at high temperature and stresses. Ni based super alloys and austenitic steels were considered to be excellent choice of material due to their close-packed structure. Austenitic stainless steels have high creep resistance but their void swelling resistance is lower compared to ferritic/martensitic steels. The void swelling resistance in austenitic stainless steel can be improved by strengthening with nano-sized stable oxide particles with high density and uniform distribution in the matrix. The interface "matrix-nanooxide" can serve as effective sink for radiation-induced point defects and increases the void swelling resistance. So, oxide dispersion-strengthened (ODS) austenitic stainless steels can be an attractive material because of their corrosion resistance, high-temperature strength and irradiation properties [2].

Apart from the void swelling neutron irradiation also degrades the mechanical performance of the austenitic stainless steels during the operation. Irradiation induced hardening due to irradiation defects and helium embrittlement are essential degradation issues encountered with nuclear structure materials. Early studies mainly focused on the macroscopic mechanical properties of steels after irradiation, but studies on crucial aspects such as microstructural evolution, the effect of inert gas implantation, and the interaction with different microstructural characteristics are rare.

Heavy ion irradiation is commonly used technique to simulate neutron damage under reactor conditions, due to the short periods of time needed to reach relatively high damage levels (several years of neutron irradiation in few hours). Moreover, the samples are not activated and therefore the study is easy to perform [3]. But, ion irradiation has a significant drawback - it produces only shallow depth of damage layer, which complicates the study of mechanical properties. The solution of the problem is possible by using of nanoindentation, TEM and SEM methods that probe very small volumes of material which allow investigate the microstructural changes and mechanical properties after irradiation. 
In the present work, we applied these methods to study the changes in the mechanical properties caused by high energy argon ions irradiation of austenitic stainless steel $18 \mathrm{Cr} 10 \mathrm{NiTi}$ and its ODS version. Argon ion irradiation and nano-characterization were carried out to clarify the effect of nano-oxide particles on defect formation, argon precipitation and irradiation induced hardening.

\section{MATERIAL AND METHODS}

In this study $18 \mathrm{Cr} 10 \mathrm{NiTi}$ austenitic stainless steel and it's strengthened by $\mathrm{Y}_{2} \mathrm{O}_{3}-\mathrm{ZrO}_{2}$ nanooxides version were investigated. Commercial austenitic steel $18 \mathrm{Cr} 10 \mathrm{NiTi}$ was used as initial steel. ODS steel was produced by the mechanical alloying of steel powder with $0.5 \mathrm{wt} . \%$ of $80 \% \mathrm{Y}_{2} \mathrm{O}_{3}-20 \% \mathrm{ZrO}_{2}$ pre-synthesized nanooxides with subsequent compacting and mechanical-thermal treatment. As the result rolled types of 18Cr10NiTi-ODS steel with thickness of $200 \mu \mathrm{m}$ were obtained. More detailed technological chain of $18 \mathrm{Cr} 10 \mathrm{NiTi}-\mathrm{ODS}$ steel production is described in [4].

Irradiation experiments were conducted in the accelerating-measuring system "ESU-2" [5]. The polished samples were irradiated with a $1.4 \mathrm{MeV} \mathrm{Ar}^{+}$ion beam at irradiation temperatures of 300 and $873 \mathrm{~K}$. The error in the temperature measurement did not exceed $\pm 5 \%$. The error in the beam current and, consequently of the damage dose, did not exceed $\pm 10 \%$.

Calculated by SRIM 2008 [6] depth distribution profiles of damage and concentration of Ar atoms implanted in $18 \mathrm{Cr} 10 \mathrm{NiTi}$ steel to a dose of $1 \cdot 10^{17} \mathrm{~cm}^{-2}$ are shown in Fig. 1. The damage calculations are based on the Kinchin-Pease model (KP), with a displacement energy for each alloying element was set to $40 \mathrm{eV}$, as recommended in ASTM E52196 (2009) [7]. The average damage level of 50 dpa over the whole projective ranges of $\mathrm{Ar}^{+}$ions instead of the peak damage level was used.

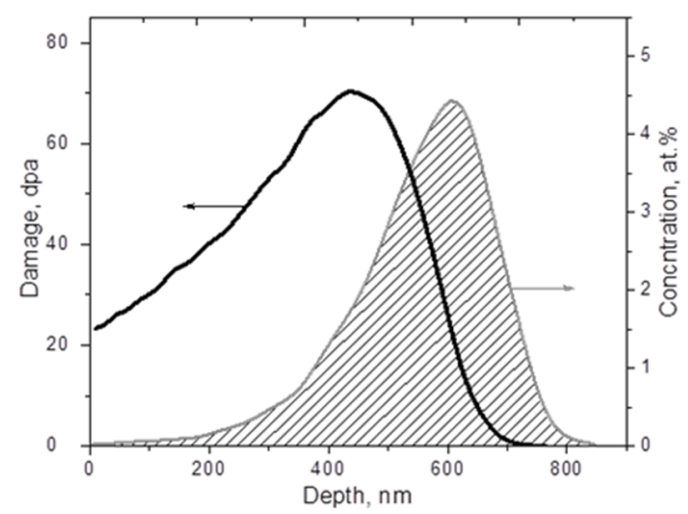

Figure 1. The depth distribution of damage and concentration of Ar atoms calculated with SRIM for $18 \mathrm{Cr} 10 \mathrm{NiTi}$ irradiated by $1.4 \mathrm{MeV}$ Ar ions to a dose of $1 \cdot 10^{17} \mathrm{~cm}^{-2}$

Nanohardness was measured by Nanoindenter G200 with a Berkovich type indentation tip. Each sample was applied at least 20 prints at a distance of $35 \mu \mathrm{m}$ from each other. Nominal maximum displacement of $2000 \mathrm{~nm}$ was used for all measurements on unirradiated and ion-irradiated steel [8]. The methodology of Oliver and Pharr was used to find the hardness [9].

Microstructural and cavities parameter data were extracted using conventional techniques conducted on JEM100CX and JEM-2100 transmission electron microscopes, employing standard bright-field techniques. Analysis of TEM micrographs was performed using image processing software. For transmission studies, samples of $18 \mathrm{Cr} 10 \mathrm{NiTi}$ austenitic stainless steel and its ODS version were prepared as disks of $3 \mathrm{~mm}$ in diameter, which were mechanically thinned to a thickness of $0.22 \mathrm{~mm}$, and then electropolished. To obtain a hole the thickness of the samples was reduced by standard jet electropolishing in a Tenupol installation in an electrolyte of $80 \% \mathrm{C}_{2} \mathrm{H}_{5} \mathrm{OH}, 10 \% \mathrm{HClO}_{4}, 10 \% \mathrm{C}_{3} \mathrm{H}_{8} \mathrm{O}_{3}$ at a voltage of $70 \mathrm{~V}$ at room temperature. TEM in kinematic bright-field mode was primarily used to characterize radiation-induced structures.

We divided the whole implantation range into four regions for statistical analysis of the cavity size and volume density in each region. To remove a specified depth layer of material from irradiated side of the sample the electropulse technique was used and then TEM studies were carried out [10]. The swelling value was calculated from the cavity size and density within each depth region. The thickness of TEM samples was determined using a convergent beam electron diffraction (CBED) pattern acquired in the two-beam approximation [11]. The thickness estimation method is based on a comparison of the measured and simulated intensity profiles across the diffraction disc. Secondary electron images produced in SEM were used for investigations of as-received and irradiated specimens in regions surrounding indents.

Structural study of samples was carried out on X-ray diffractometer DRON-2.0 in Co-K $\alpha$ radiation equipped with selective absorbing $\beta$-filter and scintillation detector. All diffraction patterns were collected under the same conditions. Standard processing was carried out for diffraction patterns (background subtraction, stripping of the Ka2 doublet, approximation of the diffraction peaks by the pseudo-Voigt function) to obtain the characteristics of the peaks (diffraction angle $2 \theta$, intensity I, integral width $\mathrm{B}$, interplanar spacing d) required for further calculations. 


\section{RESULTS AND DISCUSSION}

The initial pre-irradiation microstructures of $18 \mathrm{Cr} 10 \mathrm{NiTi}$ steel and its ODS version are shown in Fig. 2. The structure of $18 \mathrm{Cr} 10 \mathrm{NiTi}$ steel (see Fig. 2a) contains annealing twins, precipitates of second phase (carbides and titanium carbonitrides) and dislocations. Majority of perfect dislocation are extended on partial dislocation with stacking fault formation. Total dislocations density was $\sim 10^{8} \mathrm{~cm}^{-2}$; average grain size was $\sim 30 \mu \mathrm{m}$.

Grain structure of ODS steel (see Fig. 2b) is characterized by fine grains (average grain size was 1.2..2.0 $\mu \mathrm{m}$ ) and significant concentration of precipitates with near-uniform distribution. Precipitation's size varied from several nanometers to hundreds of nanometers, but the last were a few orders less, thus, its contribution to concentration and average size was negligible.

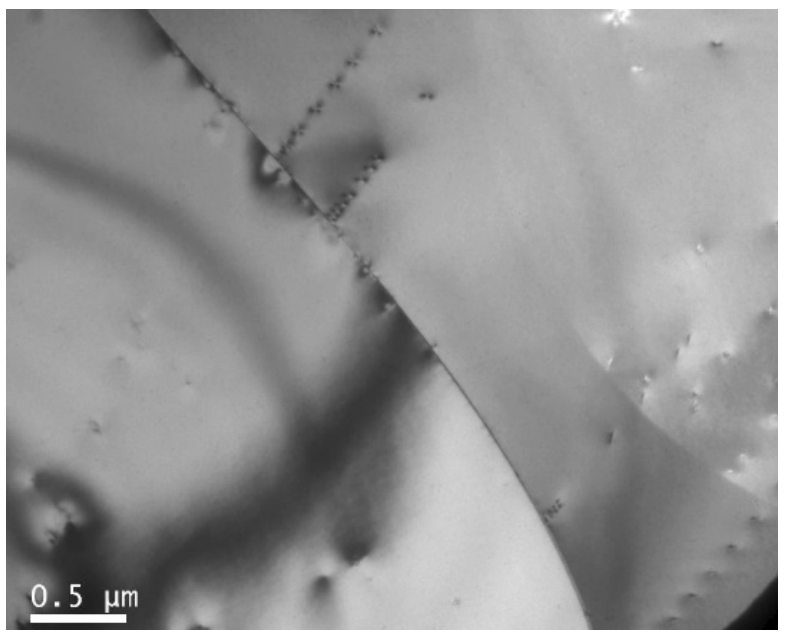

a

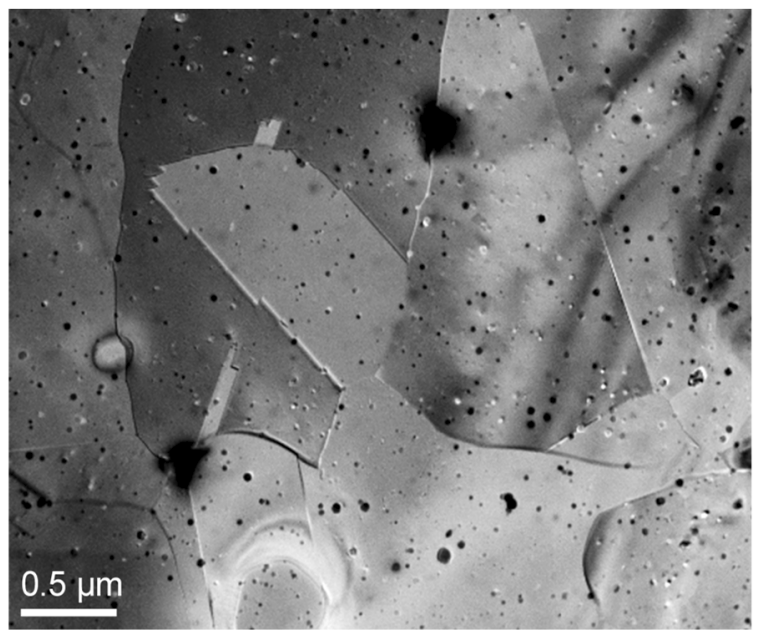

b

Figure 2. Initial structure of $18 \mathrm{Cr} 10 \mathrm{NiTi}$ steel (a) and its ODS version (b)

XRD spectra of unirradiated and $\mathrm{Ar}^{+}$ion irradiated samples of $18 \mathrm{Cr} 10 \mathrm{NiTi}$ steel and $18 \mathrm{Cr} 10 \mathrm{NiTi}$-ODS steel at temperatures of $300 \mathrm{~K}$ and $873 \mathrm{~K}$ are shown in Fig.3-8, results of XRD analysis are summarized in Table 1. All diffraction patterns were collected under the same conditions. The following samples were taken for analysis:

\#1. as-received sample of $18 \mathrm{Cr} 10 \mathrm{NiTi}$ steel;

\#2. $18 \mathrm{Cr} 10 \mathrm{NiTi}$ steel after $\mathrm{Ar}^{+}$irradiation at $\mathrm{T}=300 \mathrm{~K}$;

\#3. $18 \mathrm{Cr} 10 \mathrm{NiTi}$ steel after Ar+ irradiation at $\mathrm{T}=873 \mathrm{~K}$;

\#4. initial sample of $18 \mathrm{Cr} 10 \mathrm{NiTi}-\mathrm{ODS}$ steel;

\#5. 18Cr10NiTi-ODS steel after $\mathrm{Ar}^{+}$irradiation at $\mathrm{T}=300 \mathrm{~K}$;

\#6. 18Cr10NiTi-ODS steel after $\mathrm{Ar}^{+}$irradiation at $\mathrm{T}=873 \mathrm{~K}$.

The diffraction patterns of $18 \mathrm{Cr} 10 \mathrm{NiTi}$ steel samples in as-received state and after $\mathrm{Ar}^{+}$irradiation are virtually the same (Figs. 3-5). These samples are single-phase and consist of austenite Fe-based $\gamma$-phase with a lattice parameter a $=$ $3.5916 \pm 5 \cdot 10^{-4} \AA$. The intensity distribution of the austenite peaks corresponds to a weak crystallographic texture (111). The diffraction lines are rather narrow, which indicates a coarse-grained state.

In XRD spectra of unirradiated 18Cr10NiTi-ODS steel (Fig. 6) only austenite Fe-based $\gamma$-phase with a lattice parameter a $=3.5891 \pm 5 \cdot 10^{-4} \AA$ is observed. The peaks intensity distribution corresponds to the crystallographic texture (220). The diffraction peaks are rather narrow indicating a coarse-grained state. After $\mathrm{Ar}^{+}$ion irradiation at $873 \mathrm{~K}$ (Fig. $8)$ no significant change in the structure of ODS-steel is observed. The lattice parameter of austenite $\left(\mathrm{a}=3.5896 \pm 5 \cdot 10^{-}\right.$ ${ }^{4} \AA$ ) does not change within the measurement error.

XRD pattern of $18 \mathrm{Cr} 10 \mathrm{NiTi}$-ODS steel after $\mathrm{Ar}^{+}$irradiation at $300 \mathrm{~K}$ demonstrated some differences compared to abovementioned cases. In addition to peaks of Fe-based $\gamma$-phase which are fully correspond to those ones of the unirradiated sample a distinguishable broadened peak on the left of the (220) matrix peak was observed (Fig. 7). This peak could be attributed to the damaged matrix within the implanted layer. In this case, $\mathrm{Ar}^{+}$ion irradiation has two effects on the structure. First of all, irradiation-induced defects are pinned by nanooxide particles in the surface layer. Accumulation of dislocations (dislocation walls) in implanted layer leads to the formation of small domains separated by the dislocations induced local lattice rotations. Also, microstrain appears in this layer due to the radiation-induced formation of chaotically oriented dislocations. Both small domains size and microstrain cause peak broadening [12, 13]. Moreover, the presence of a large number of dislocation loops is confirmed by TEM micrographs (Fig. 9, a) and their number is significantly higher at $300 \mathrm{~K}$. Second, irradiation at $300 \mathrm{~K}$ leads to dissolution of nanooxide precipitates [14]. Dissolution of nanooxides elements $(\mathrm{Y}, \mathrm{Zr}$ and $\mathrm{O})$ in implanted layer increases lattice parameter and as a consequence peak shift towards the smaller $2 \theta$ angles is observed. Also swelling causes a residual stress in the implanted layer [15], which affects the peak shift too. It should be noted, that this effect is observed only at low irradiation temperature, while at $873 \mathrm{~K}$ it appears to be compensated due to the high diffusion mobility of radiation-induced defects. 


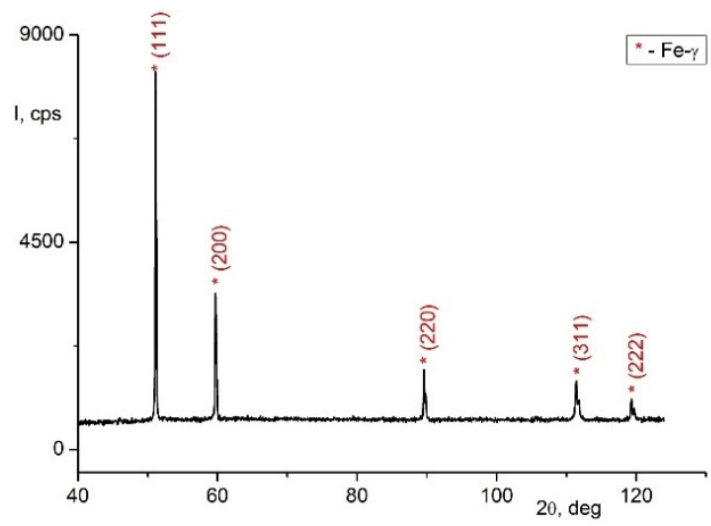

Figure 3. Diffraction pattern of sample \#1.

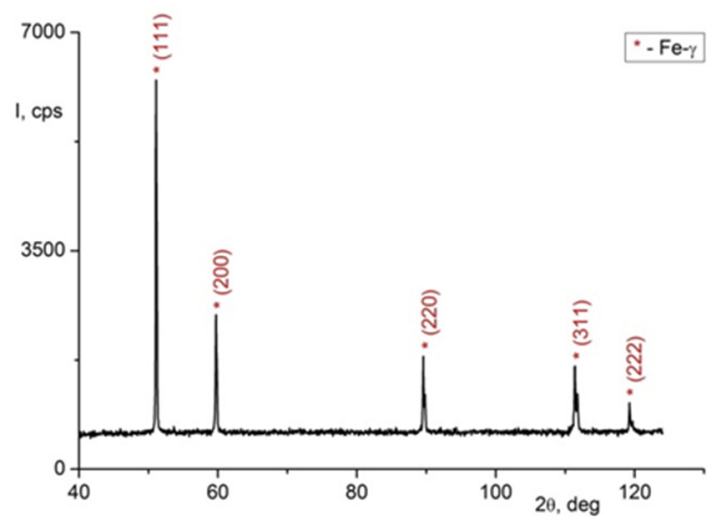

Figure 5. Diffraction pattern of sample \#3.

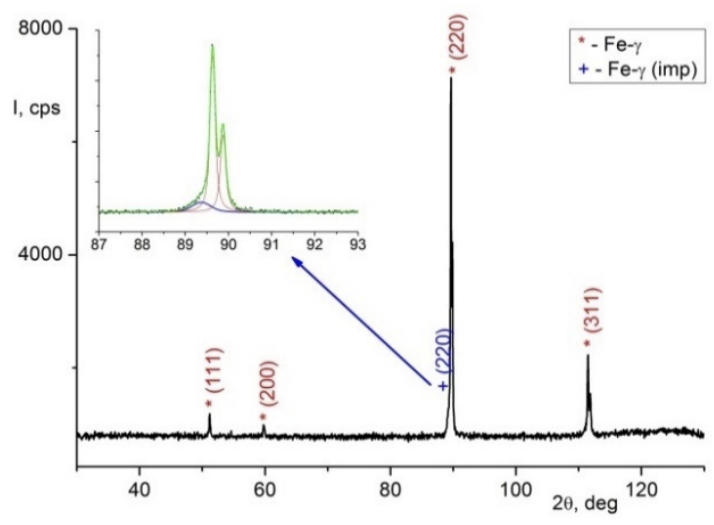

Figure 7. Diffraction pattern of sample $\# 5$.

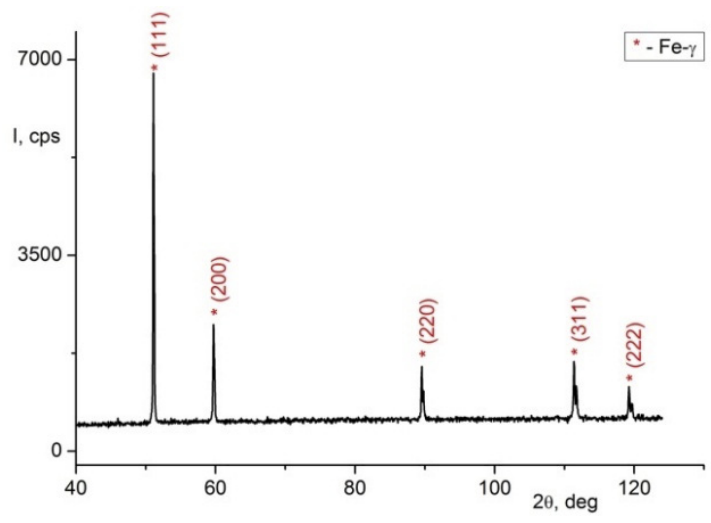

Figure 4. Diffraction pattern of sample \#2.

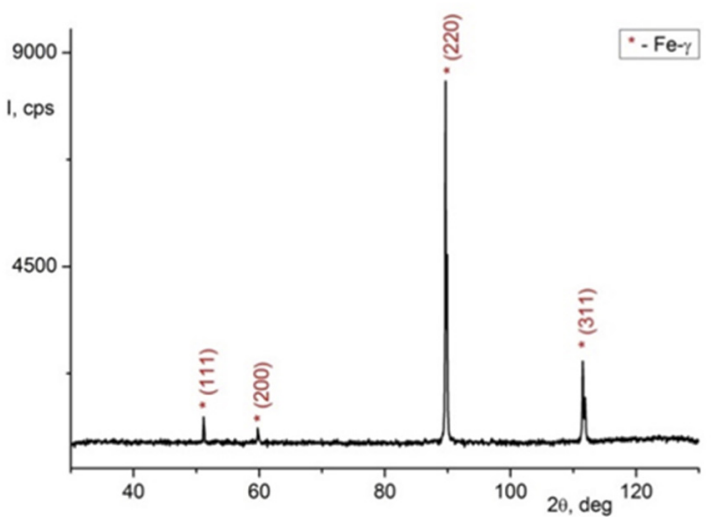

Figure 6. Diffraction pattern of sample \#4.

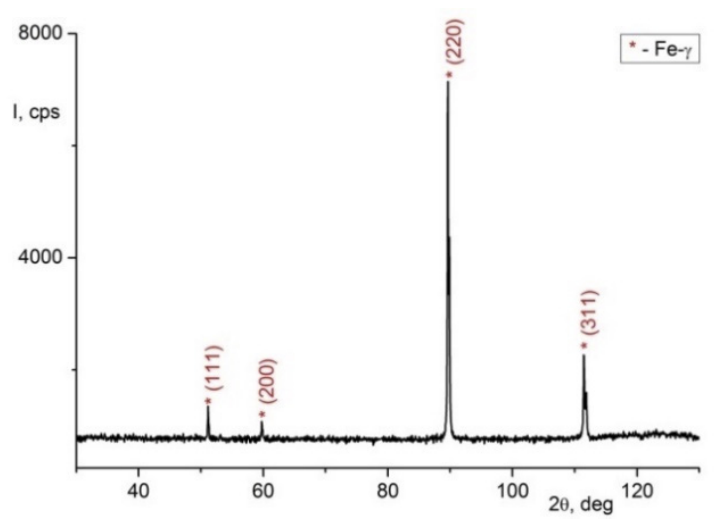

Figure 8. Diffraction pattern of sample \#6.

Table 1. Phase composition and lattice parameters of investigated samples

\begin{tabular}{|c|c|c|}
\hline $\begin{array}{c}\text { Sample } \\
\#\end{array}$ & $\begin{array}{c}\text { Phase } \\
\text { composition }\end{array}$ & $\begin{array}{c}\text { Lattice } \\
\text { parameter, } \AA\end{array}$ \\
\hline 1 & $\mathrm{Fe}-\gamma$ & 3.5915 \\
\hline 2 & $\mathrm{Fe}-\gamma$ & 3.5917 \\
\hline 3 & $\mathrm{Fe}-\gamma$ & 3.5916 \\
\hline 4 & $\mathrm{Fe}-\gamma$ & 3.5891 \\
\hline \multirow{2}{*}{5} & $\mathrm{Fe}-\gamma$ & 3.5896 \\
\cline { 2 - 3 } & $\mathrm{Fe}-\gamma(\mathrm{imp})$ & 3.595 \\
\hline 6 & $\mathrm{Fe}-\gamma$ & 3.5896 \\
\hline
\end{tabular}

Fig. 9 shows TEM micrographs of $18 \mathrm{Cr} 10 \mathrm{NiTi}$ and $18 \mathrm{Cr} 10 \mathrm{NiTi}-\mathrm{ODS}$ steel samples irradiated with Ar ions to average dose of $50 \mathrm{dpa}$ at room temperature (RT). In the region of the first $200 \mathrm{~nm}$, irradiation-induced defects of very small-sized "black spots" and dislocation loops were observed (Fig. 9 a, c). These defects disappeared upon tilting of 
sample by small degrees indicating that these are not precipitates. Fig. 9 b, d represents through-focus micrographs where some very small cavities are observed at the depth near $450 \mathrm{~nm}$ from surface.

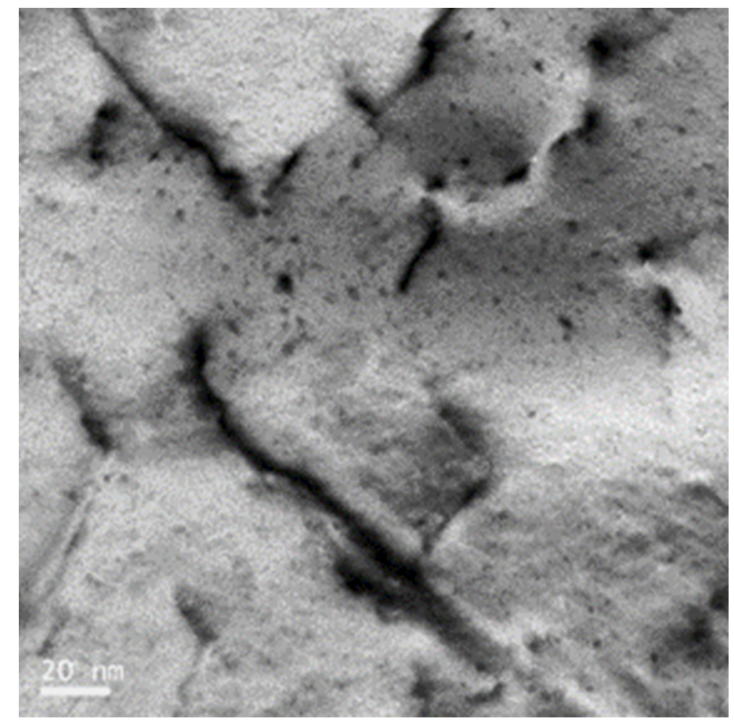

a

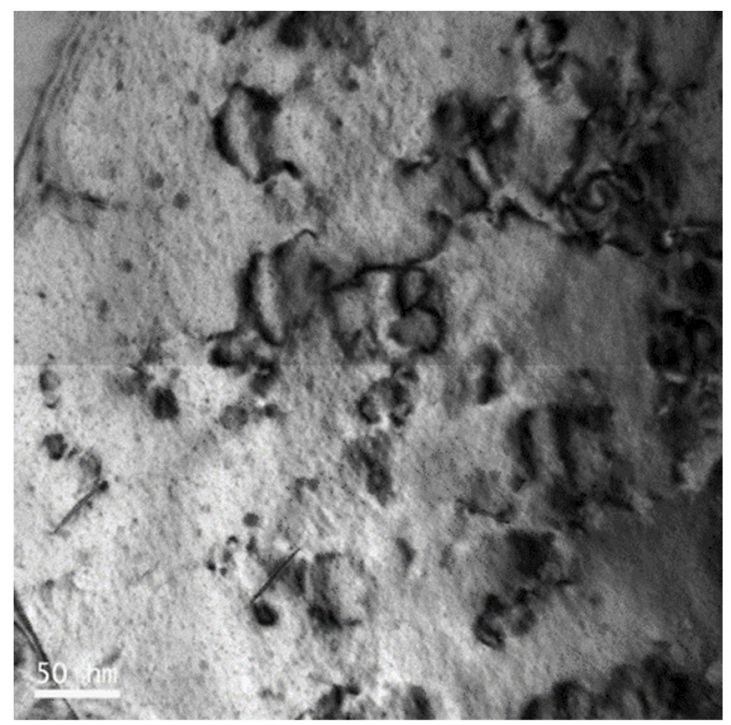

c

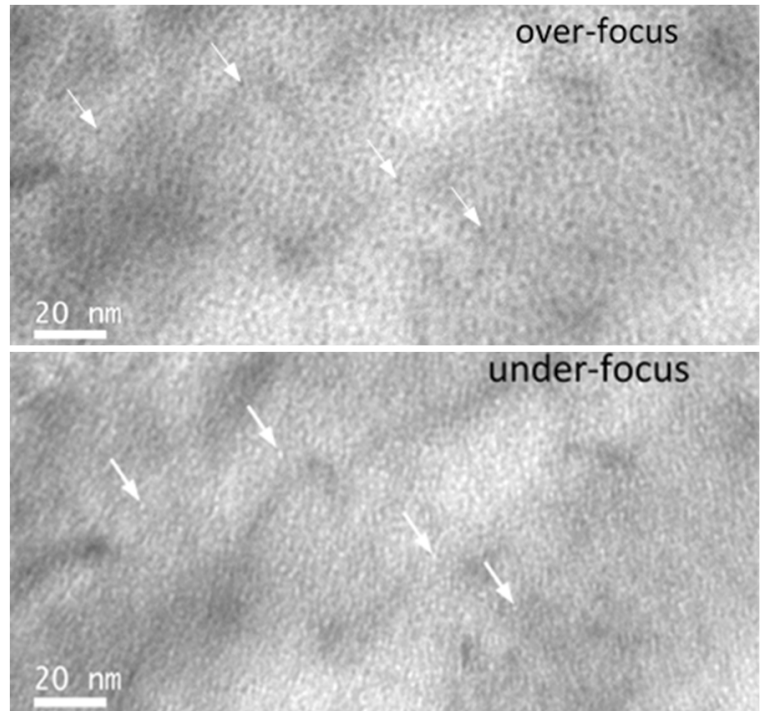

b
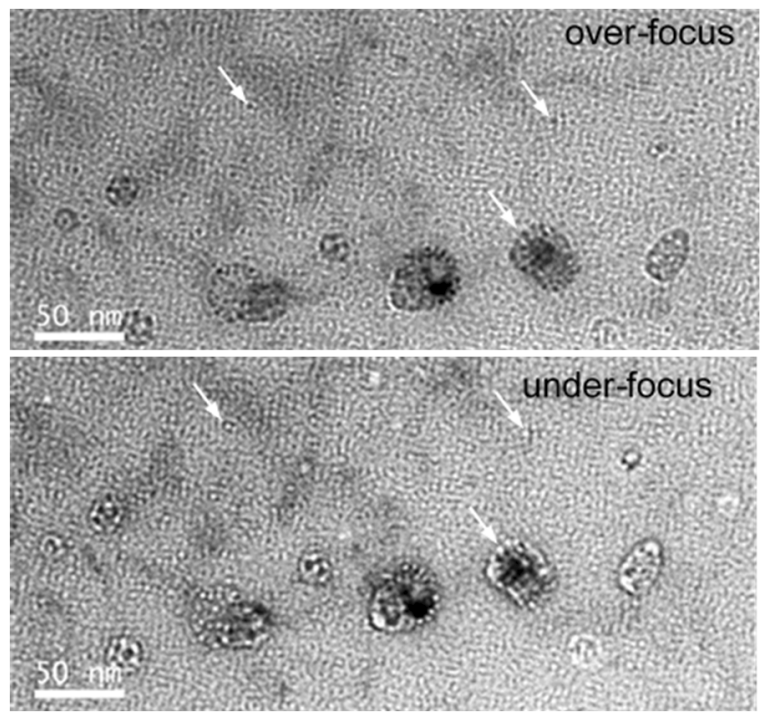

d

Figure 9. The microstructure of $18 \mathrm{Cr} 10 \mathrm{NiTi}(\mathrm{a}, \mathrm{b})$ and $18 \mathrm{Cr} 10 \mathrm{NiTi}-\mathrm{ODS}(\mathrm{c}, \mathrm{d})$ at specified depth after irradiation at $300 \mathrm{~K}$. (a, c) at the depth $100 \mathrm{~nm}$ from surface, $(\mathrm{b}, \mathrm{d})$ - at the depth $450 \mathrm{~nm}$ from surface, pointing with arrows some very small cavities with a size $\sim 1 \mathrm{~nm}$, over-focused image $+1000 \mathrm{~nm}$ (black cavities), under-focused image $-1000 \mathrm{~nm}$ (white cavities).

The detection of cavities in the Ar irradiated steels at RT was complicated due to their small size. A high error must be considered for cavity sizes below $1 \mathrm{~nm}$ due to the amount of defocus used to detect them. Depending on the specimen thickness its value was $\sim 1 \mu \mathrm{m}$ in absolute values. The mean size of the cavities was $1.3 \mathrm{~nm}$ with the number density $1.5 \cdot 10^{24} \mathrm{~m}^{-3}$ for $18 \mathrm{Cr} 10 \mathrm{NiTi}$ and $2-3 \mathrm{~nm}$ with $5 \cdot 10^{23} \mathrm{~m}^{-3}$ for $18 \mathrm{Cr} 10 \mathrm{NiTi}$-ODS steels. Random distribution was found, they seem not to be attached to any microstructural sinks which would indicate that the nucleation was preferential.

As the temperature of irradiation increases to $873 \mathrm{~K}$, the process passes to another stage: the swelling gradually increases. Fig. 10 shows TEM micrographs of Ar implanted $18 \mathrm{Cr} 10 \mathrm{NiTi}$ at specified depths. The higher dpa and Ar clearly lead to increased cavity size, primarily due to the presence of more numerous and larger faceted cavities (see Fig. 8, c).

Fig. 11 shows microstructure of $18 \mathrm{Cr} 10 \mathrm{NiTi}-\mathrm{ODS}$ steel at specified depth after argon ion irradiation at $873 \mathrm{~K}$. Most cavities in ODS-steel seems to be rounded, however, there are also faceted cavities. Despite the fact that significant concentration of precipitates was distributed near-uniform over the sample, areas with reasonably inhomogeneous distribution of cavities throughout the matrix and from grain to grain and even within the same grain are observed.

Cavities observed around the precipitates have a density increased by several times and an average diameter in 2-3 times smaller than the cavities formed far from the precipitates (see some cavity clusters highlighted with ovals in 
Fig. 11b,). High vacancy concentration as well as high argon atoms content contribute to the formation of porous structure both in conventional and in ODS-modified alloys. The enhanced cavities nucleation is attributed to the ability of argon to trap vacancies and stabilize them [16]. However, at the stage of cavity growth, the inflow of vacancies will be limited in the case of ODS-steel, because a significant part of the vacancies will drift towards the semicoherent matrix/precipitation interfaces to compensate for microstrains.

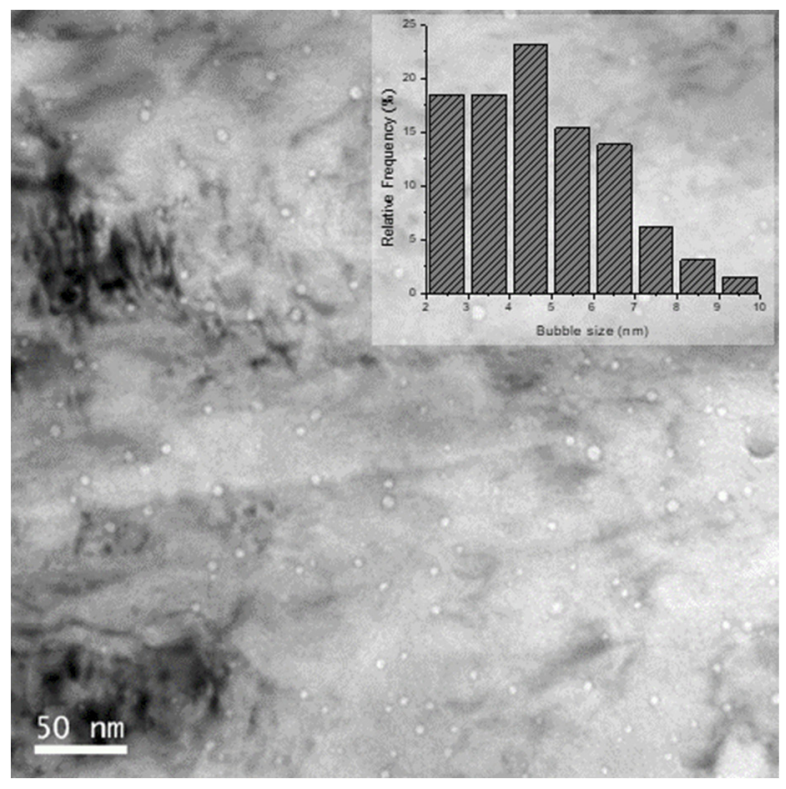

a

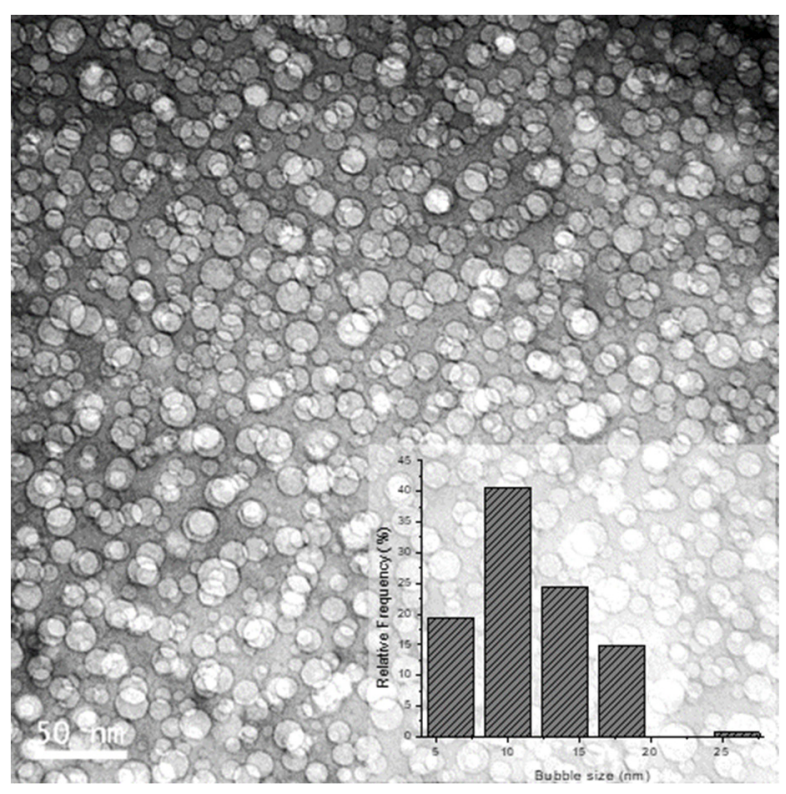

c

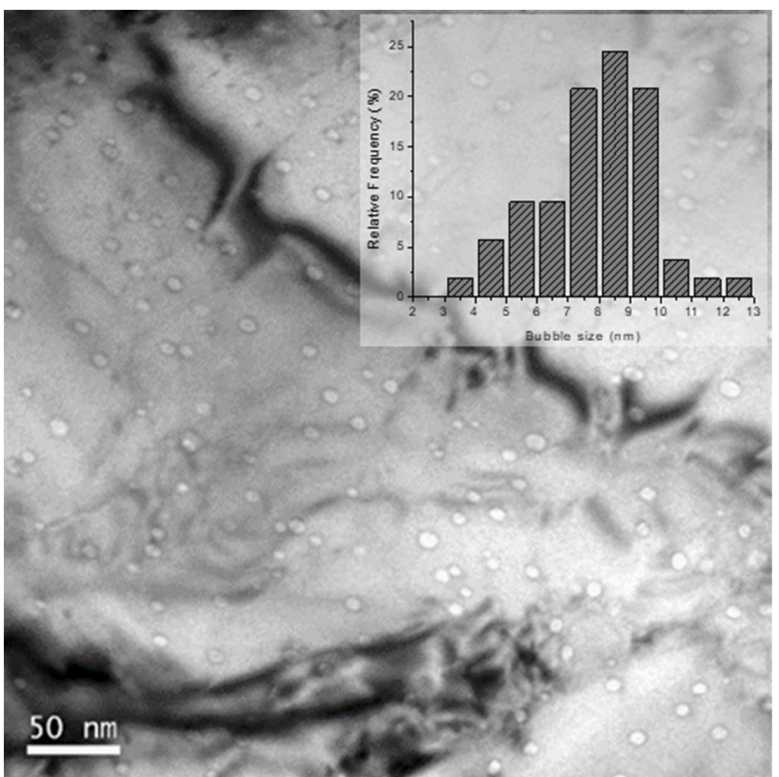

b

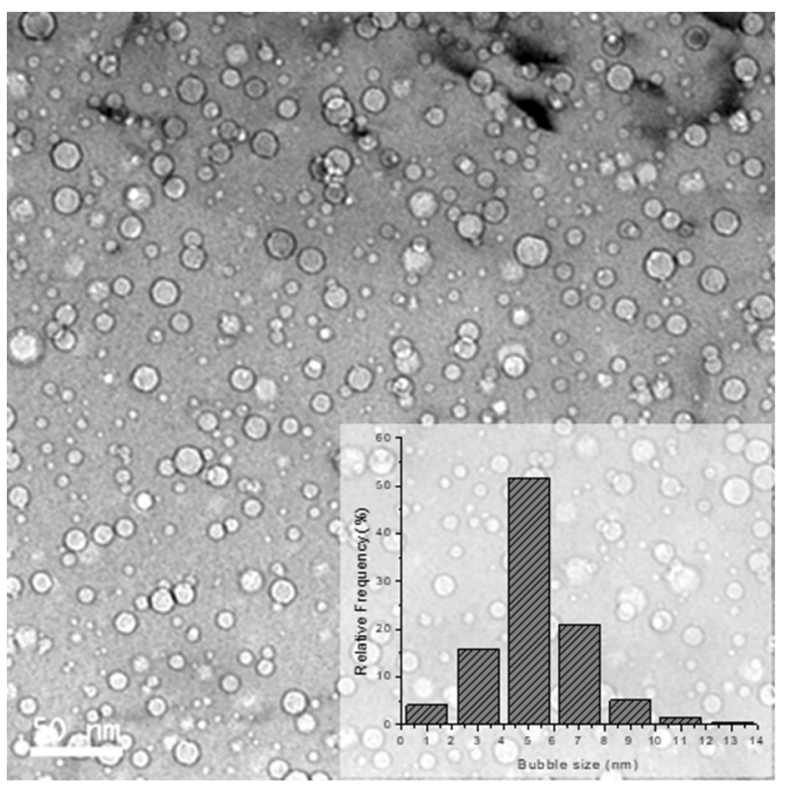

d

Figure 10. Microstructure of 18Cr10NiTi steel at specified depth 100 (a), 250 (b), 450 (c) and $750 \mathrm{~nm}$ (d) after Ar irradiation at 873 K. Cavity size distributions in steel are shown in the inserts.

The evolution of cavities diameter, density and swelling with depth for 18Cr10NiTi and 18Cr10NiTi-ODS steels irradiated with Ar ions to a dose of $50 \mathrm{dpa}$ at $873 \mathrm{~K}$ is shown in Fig. 12. With increasing depth, the bubble sizes and densities increase up to the peak dpa region (450 nm depth) and then subsequently decrease beyond the Ar implantation peak region. The average cavity size in ODS-steel is smaller than in base $18 \mathrm{Cr} 10 \mathrm{NiTi}$. The depth dependences of cavity number density are virtually the same for both types of investigated steels. 18Cr10NiTi-ODS demonstrated good resistance to swelling. The swelling was estimated to be almost half for $18 \mathrm{Cr} 10 \mathrm{NiTi}$-ODS (4.8 \%) compared to $18 \mathrm{Cr} 10 \mathrm{NiTi}(9.4 \%)$. These data suggest that the fine dispersed oxide particles are obviously effective in suppression of cavity coarsening and contributes to limiting defect clusters to small size. Part of oxide particles seems to be incoherent with respect to the matrix from TEM observations. This gives a hint that the oxide/matrix interface is the neutral sink for point defects as well as grain boundaries. 


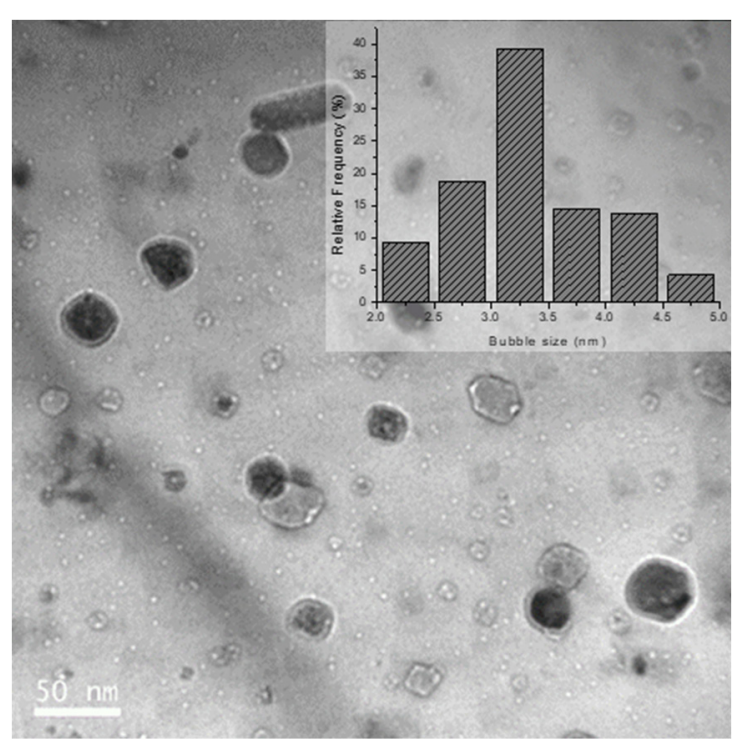

a

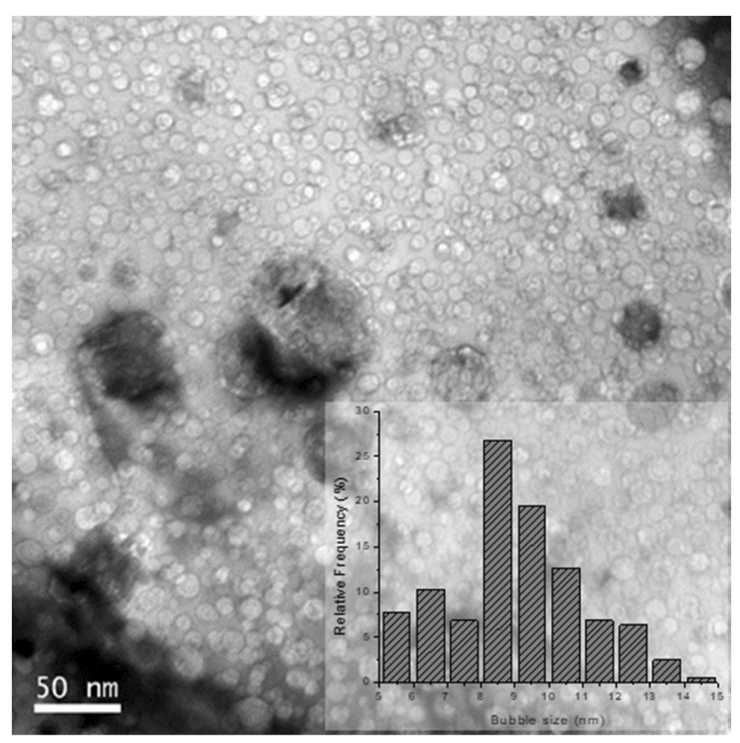

c

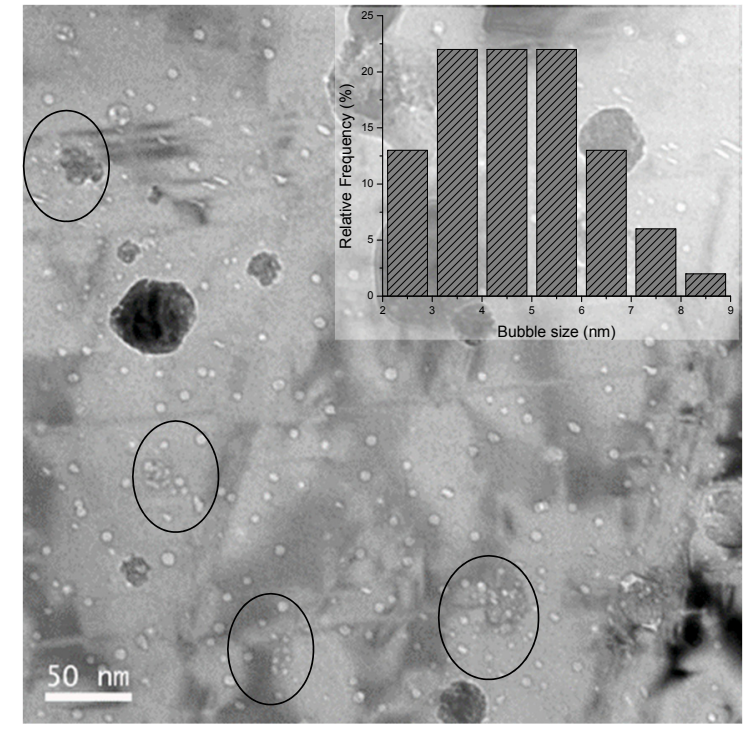

b

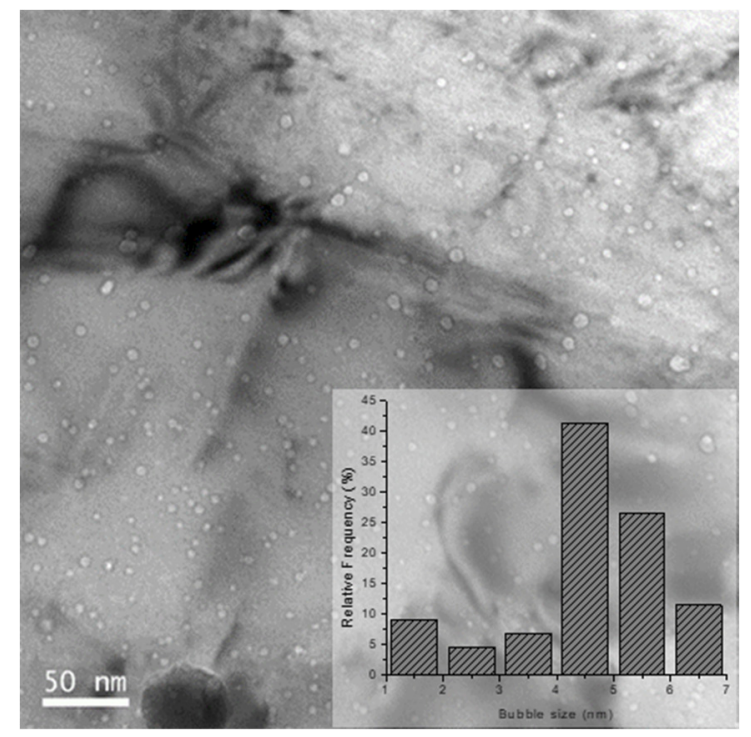

d

Figure 11. Microstructure of 18Cr10NiTi-ODS steel at specified depth 100 (a), 250 (b), 450 (c) and $750 \mathrm{~nm}$ (d) after Ar irradiation at 873 K. Cavity size distributions in steel are shown in the inserts.

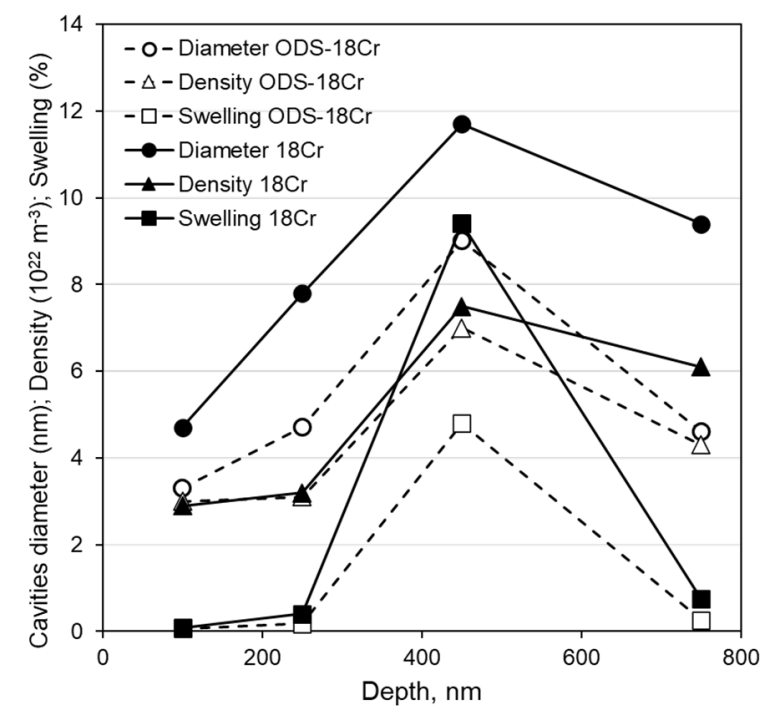

Figure 12. Depth dependences of cavities diameter, volume density and cavity swelling at different depths in $18 \mathrm{Cr} 10 \mathrm{NiTi}$ and $18 \mathrm{Cr} 10 \mathrm{NiTi}-\mathrm{ODS}$ steels irradiated of Ar ions to average dose 50 dpa at $873 \mathrm{~K}$ 
Fig. 13 shows the hardness as a function of the indenter displacement for unirradiated and irradiated $18 \mathrm{Cr} 10 \mathrm{NiTi}$ and 18Cr10NiTi-ODS steels at RT and $873 \mathrm{~K}$. For all samples in the first $150 \mathrm{~nm}$, there is a significant scatter in the data through indenter tip artifacts and surface preparation effects. Therefore, data for the first $150 \mathrm{~nm}$ will be ignored in the rest of the analysis. There are no indications of the formation of pile-up lobes or localized slip steps indent in the unirradiated steels. The irradiated samples also showed virtual, if any, pile-up effect. For this reason, a contact area correction for the pile-up was not attempted.

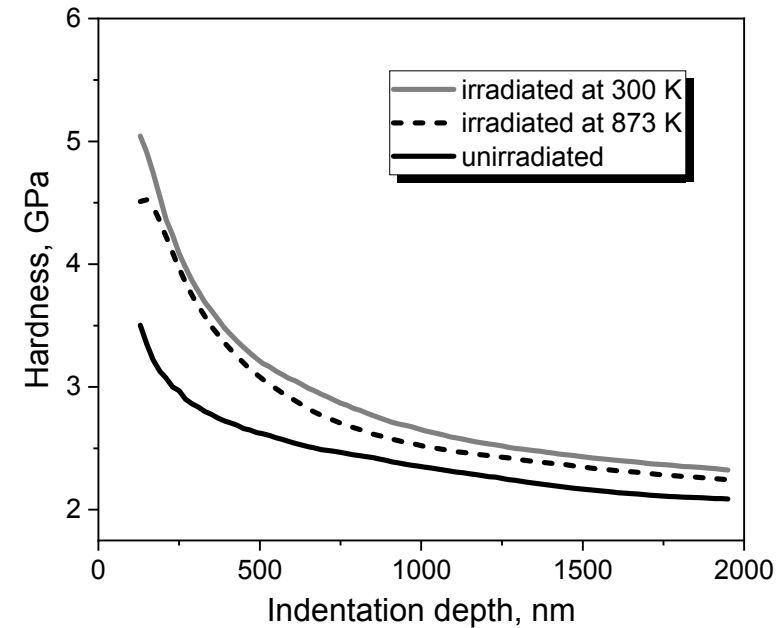

a

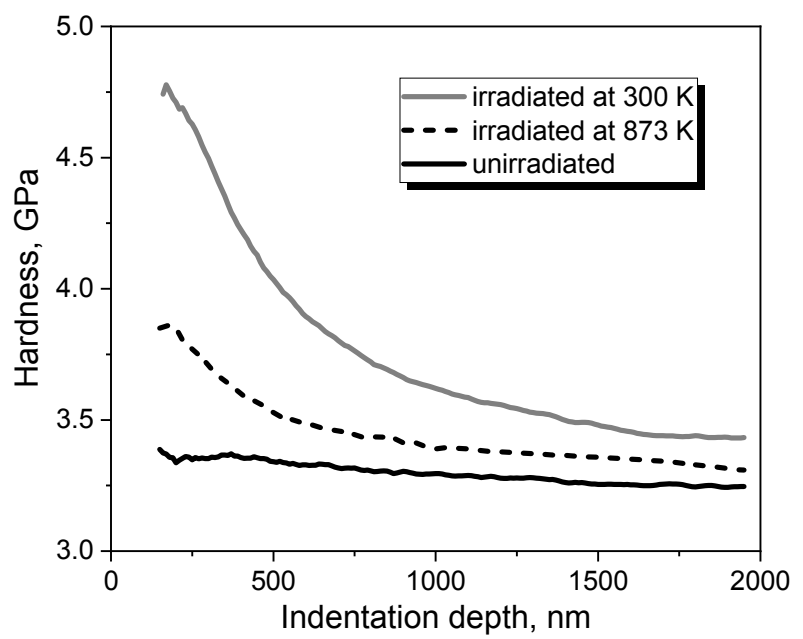

c

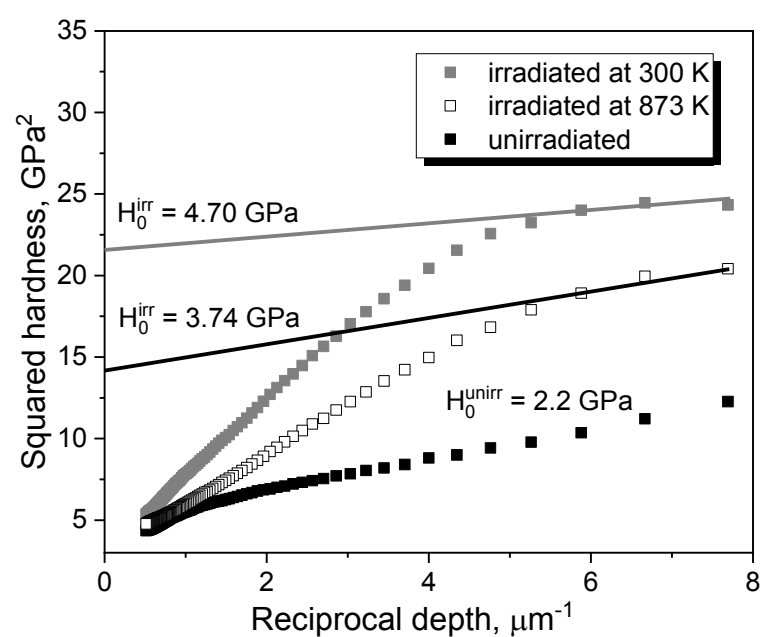

b

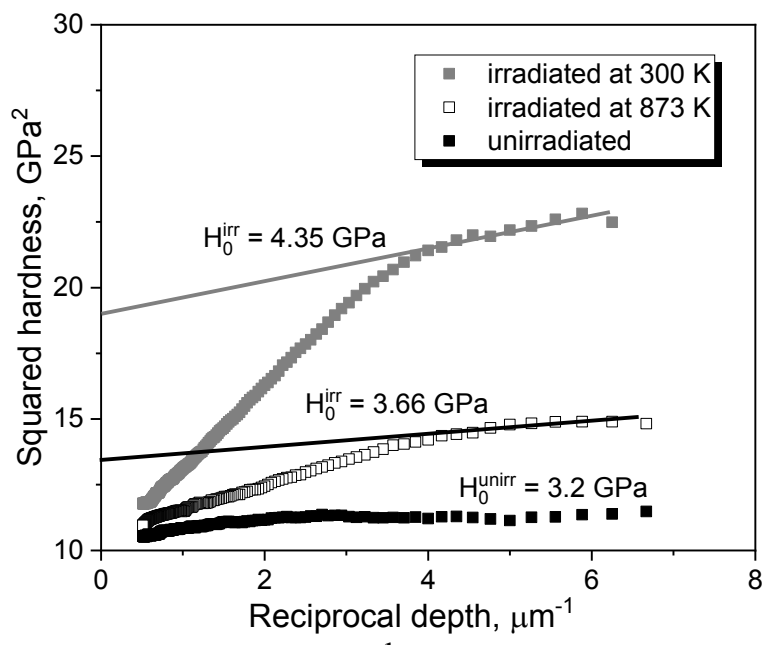

d

Figure 13. An averaged nanohardness vs indentation depth $(a, c)$ and plots of the square of nanoindentation hardness against the reciprocal of indentation depth $(b, d)$ for unirradiated and irradiated at 300 and $873 \mathrm{~K}$ sample of $18 \mathrm{Cr} 10 \mathrm{NiTi}(\mathrm{a}, \mathrm{b})$ and 18Cr10NiTi-ODS (c, d).

Irradiation with Ar ions up to a dose of $50 \mathrm{dpa}$ at RT and $873 \mathrm{~K}$ leads to an increase in nanohardness of implanted layer. By redrawing the hardness profile in terms of Nix-Gao [17] plot (squared hardness vs. reciprocal depth), the bulkequivalent hardness $\mathrm{H}_{0}$ has been evaluated (see Fig. 13 and Table 2). Comparison of the radiation-induced hardening $(\Delta \mathrm{H}$, the difference of hardness values of irradiated and unirradiated materials) and the corresponding nanohardness increments described as the ratio of $\triangle \mathrm{H}$ and $\mathrm{H}_{0}{ }^{\text {unirr }}$ shows some differences in the data, that are likely to be associated with the difference in the irradiation temperature and microstructure.

Table 2. Experimentally determined the bulk-equivalent hardness and hardening.

\begin{tabular}{|c|c|c|c|c|c|c|}
\hline \multirow{2}{*}{ Material } & \multicolumn{3}{|c|}{$18 \mathrm{Cr} 10 \mathrm{NiTi}$} & \multicolumn{3}{c|}{ 18Cr10NiTi-ODS } \\
\cline { 2 - 7 } & $\mathrm{H}_{0}, \mathrm{GPa}$ & $\triangle \mathrm{H}, \mathrm{GPa}$ & $\triangle \mathrm{H}^{\prime} \mathrm{H}_{0}{ }^{\text {unirr }}, \%$ & $\mathrm{H}_{0}, \mathrm{GPa}$ & $\triangle \mathrm{H}, \mathrm{GPa}$ & $\triangle \mathrm{H} / \mathrm{H}_{0}{ }^{\text {unirr }}, \%$ \\
\hline unirradiated & 2.2 & & & 3.2 & & \\
\hline irradiated at RT & 4.70 & 2.5 & 114 & 4.35 & 1.15 & 36 \\
\hline irradiated at 873 K & 3.74 & 1.54 & 70 & 3.66 & 0.46 & 14 \\
\hline
\end{tabular}

In the case of unirradiated $18 \mathrm{Cr} 10 \mathrm{NiTi}$ samples $\mathrm{H}_{0}{ }^{\text {unirr }}$ was estimated as $2.2 \mathrm{GPa}$, while for $18 \mathrm{Cr} 10 \mathrm{NiTi}-\mathrm{ODS}$ samples this value was $3.2 \mathrm{GPa}$. A significant increase in hardness of unirradiated 18Cr10NiTi-ODS appears to be due to the grain refinement and precipitates as yttrium oxides. 
Generally, irradiation assisted hardening in fcc metals is associated with the formation of Frank loops which, being sessile in nature, strongly impede the movement of dislocations [3, 18-20]. However, in the present study the main radiation-induced hardening effect is attributed to cavities formation. Although "black spot" defects, which are believed to be Frank loops, were also detected, their occurrence was observed mainly in a narrow near-surface region of irradiated sample (see Fig. 9). Strong dominance of cavity-type defects was revealed by TEM analysis at greater depths. Observed microstructure transformation appears to be due to the high damaging dose (50 dpa), which is forcedly associated with the accumulation of a noticeable amount of gas impurity in depth range of 200-800 nm (see Fig. 1). Due to dpa and gas concentration gradient, different types of cavities can be formed. Depending on vacancy/Ar ratio and, accordingly, internal gas pressure, the effectiveness of these cavities as obstacles to dislocation motion can vary.

According to the data of Table 2, the hardening of $18 \mathrm{Cr} 10 \mathrm{NiTi}$-ODS is a much lower than that of $18 \mathrm{Cr} 10 \mathrm{NiTi}$ after Ar ion irradiation at RT. The presence of precipitates as yttrium oxides leads to the formation of nano-sized cavities with a larger size and lower number density in 18Cr10NiTi-ODS compared to conventional steel. For this reason, less hardening effect was observed in 18Cr10NiTi-DS, although the contribution of residual stress observed by $\mathrm{XRD}$ analysis in damaged layer of ODS-steel is also possible.

Irradiation at $873 \mathrm{~K}$ leads to less increase in hardness in both alloys compared to RT irradiation. Meanwhile, the difference in hardening between two steels after $873 \mathrm{~K}$ irradiation has become even greater. Observed tendencies appear to be associated primarily with high diffusivity of radiation-induced point defects, and gas atoms and their intensive interaction with sinks such as grain boundaries and precipitates. These processes substantially influence cavities formation and evolution. The fine dispersed oxide particles are obviously effective in suppression of cavity coarsening and contributes to limiting defect clusters to small size. At the same time, the fine-grained structure of $18 \mathrm{Cr} 10 \mathrm{NiTi}-$ ODS has a high density of distribution boundaries, which act as absorbers of radiation defects.

Summarizing, the phenomenon known as radiation induced hardening has been experimentally demonstrated in $18 \mathrm{Cr} 10 \mathrm{NiTi}$ austenitic stainless steel and its strengthened version. The increase in hardness values is caused by defects created during irradiation (such as cavities and dislocations), the formation of which, in turn, depends on the experimental conditions, such as radiant species nature, irradiation temperature or fluence. At evaluation of hardening behavior, it is also important to take into account other microstructural characteristics (irradiation independent) such as grain boundaries, dislocations inherent to the microstructure, precipitated or added particles as yttrium oxides (in the case of ODS). Thus, by the collection of properties, oxide dispersion strengthened $18 \mathrm{Cr} 10 \mathrm{NiTi}$ austenitic stainless steel is less susceptible to radiation hardening/embrittlement compared to conventional austenitic steel.

\section{CONCLUSIONS}

In the present study, we applied the methods of ion irradiation, nanoindentation, XRD analysis, scanning and transmission electron microscopy to investigate the evolution of microstructure and mechanical properties of irradiated $18 \mathrm{Cr} 10 \mathrm{NiTi}$ austenitic stainless steel and its ODS-modified version. ODS-steel was produced on the basis of conventional $18 \mathrm{Cr} 10 \mathrm{NiTi}$ austenitic steel by mechanical alloying with nano-oxide particles. Argon ion irradiation was carried out to clarify the effect of oxide particles on defect formation, argon precipitation and irradiation induced hardening.

XRD analysis showed no significant changes in the structure of irradiated specimens, with the exception of domains refinement and microstrain appearance in ODS-steel after irradiation at room temperature.

Layer-by-layer TEM analysis revealed spatial distribution of radiation-induced defects along the damage profile. Dislocations and cavity-like defects were observed in both steels. The higher dpa and Ar concentration clearly lead to increased cavities size and their number density. The swelling was estimated to be almost half for 18Cr10NiT-ODS (4.8\%) compared to $18 \mathrm{Cr} 10 \mathrm{NiTi}(9.4 \%)$ indicating improved swelling resistance of ODS-steel. Fine dispersed oxide particles are shown to be effective in suppression of cavity coarsening and contributes to limiting defect clusters to small size.

The main hardening effect is caused by cavities in both steels. Due to oxide particles, the hardening of 18Cr10NiTi-ODS after Ar ion irradiation at room and elevated temperatures is lower than 18Cr10NiTi. Oxide dispersion strengthened $18 \mathrm{Cr} 10 \mathrm{NiTi}$ austenitic stainless steel is less susceptible to radiation hardening/embrittlement compared with a conventional austenitic steel.

\section{ACKNOWLEDGEMENTS}

The work was financially supported by the National Academy of Science of Ukraine (program "Support of the development of main lines of scientific investigations" (KPKVK 6541230)).

\section{ORCID IDs}

DIgor Kolodiy, https://orcid.org/0000-0001-8598-9732; Oleksandr Kalchenko, https://orcid.org/0000-0003-0856-1868 (D) Sergiy Karpov, https://orcid.org/0000-0002-6607-8455; (DVictor Voyevodin, https://orcid.org/0000-0003-2290-5313

(D)Mikhail Tikhonovsky, https://orcid.org/0000-0001-5889-0366; DOleksii Velikodnyi, https://orcid.org/0000-0001-5088-6143

Dalyna Tolmachova, https://orcid.org/0000-0002-0786-2979; (Duslan Vasilenko, https://orcid.org/0000-0002-4029-9727

(DGalyna Tolstolutska, https://orcid.org/0000-0003-3091-4033 


\section{REFERENCES}

[1] V.N. Voyevodin, and I.M. Neklyudov, Evolution of the Structural-Phase State and Radiation Resistance of Structural Materials, (Kiev, Naukova Dumka, 2006). (in Russian)

[2] S.J. Zinkle, and J.T. Busby, Mat. Today, 12, 12-19 (2009), https://doi.org/10.1016/S1369-7021(09)70294-9.

[3] G.S. Was, and R.S. Averback, Comprehensive Nuclear Materials, 1, 195-221 (2012). https://doi.org/10.1016/B978-0-08056033-5.00007-0.

[4] A.N. Velikodnyi, V.N. Voyevodin, M.A. Tikhonovsky, V.V. Bryk, A.S. Kalchenko, S.V. Starostenko, I.V. Kolodiy, V.S. Okovit, A.M. Bovda, L.V. Onischenko, and G.Ye. Storogilov, PAST, 4(92), 94-102 (2014), https://vant.kipt.kharkov.ua/ARTICLE/VANT_2014_4/article_2014_4_94.pdf. (in Russian)

[5] G.D. Tolstolutskaya, V.V. Ruzhytskiy, I.E. Kopanetz, V.N. Voyevodin, A.V. Nikitin, S.A. Karpov, A.A. Makienko, and T.M. Slusarenko, PAST, 1, 135-140 (2010), https://vant.kipt.kharkov.ua/ARTICLE/VANT_2010_1/article_2010_1_135.pdf. (in Russian).

[6] R.E. Stoller, M.B. Toloczko, G.S. Was, A.G. Certain, S. Dwaraknath, and F.A. Garner, Nucl. Instrum. Methods Phys. Res. Sect. B: Beam Interact. Mater. Atoms, 310, 75-80 (2013), http://dx.doi.org/10.1016/j.nimb.2013.05.008.

[7] ASTM E521-96, 2009, ASTM, https://doi.org/10.1520/E0521-96R09E01.

[8] G.N. Tolmachova, G.D. Tolstolutskaya, S.A. Karpov, B.S. Sungurov, and R.L. Vasilenko, PAST, 5(99), 168-173 (2015), https://vant.kipt.kharkov.ua/ARTICLE/VANT_2015_5/article_2015_5_168.pdf.

[9] W.C. Oliver, and G.M. Pharr, J. Mater. Res. 7(6), 1564-1583 (1992), https://doi.org/10.1557/JMR.1992.1564.

[10] M.B. Toloczko, F.A. Garner, V.N. Voyevodin, V.V. Bryk, O.V. Borodin, V.V. Mel'nychenko, and A.S.Kalchenko, Journal of Nuclear Materials, 453, 323-333 (2014), https://doi.org/10.1016/j.jnucmat.2014.06.011.

[11] M. Klinger, Journal of Applied Crystallography, 50, 1226-1234 (2017), https://doi.org/10.1107/S1600576717006793.

[12] N.N. Kumar, R. Tewari, P. Mukherjee, N. Gayathri, P.V. Durgaprasad, G.S. Taki, J.B.M. Krishna, A.K. Sinha, P. Pant, A.K. Revally, B.K. Dutta, and G.K. Dey, Radiation Effects and Defects in Solids, 1370520, 678-694 (2017), http://dx.doi.org/10.1080/10420150.2017.1379520.

[13] P. Mukherjee, A. Sarkar, M. Bhattacharya, N. Gayathri, and P. Barat, Journal of Nuclear Materials, 395, 37-44 (2019), https://doi.org/10.1016/j.jnucmat.2009.09.013.

[14] E. Aydogan, O. El-Atwani, M. Li, and S.A. Maloy. Materials Characterization., 170, 110686 (2020). https://doi.org/10.1016/j.matchar.2020.110686.

[15] S. Ahmad, S. Bashir, D. Yousaf, and M.A. Ali, Materials Sciences and Applications, 9, 330-344 (2018), https://doi.org/10.4236/msa.2018.93022.

[16] Y. Osetsky, and Roger E. Stoller, Journal of Nuclear Materials, 465, 448-454 (2015), https://doi.org/10.1016/j.jnucmat.2015.05.034.

[17] W.D. Nix, H.J. Gao, J. Mech. Phys. Solid, 46, 411-425 (1998), https://doi.org/10.1016/S0022-5096(97)00086-0.

[18] S.A. Karpov, G.D. Tolstolutskaya, B.S. Sungurov et al., Materials Science. 52, issue 3, 377-384 (2016), https://doi.org/10.1007/s11003-016-9967-4.

[19] V.N. Voyevodin, S.A. Karpov, G.D. Tolstolutskaya, M.A. Tikhonovsky, A.N. Velikodnyi, I.E. Kopanets, G.N. Tolmachova, A.S. Kalchenko, R.L. Vasilenko, and I.V. Kolodiy, Philosophical Magazine, 100(7), 822-836 (2020), https://doi.org/10.1080/14786435.2019.1704091.

[20] D.C. Foley, K.T. Hartwig, S.A. Maloy, P. Hosemann, X. Zhang, Journal of Nuclear Materials, 389, 221-224 (2009), http://doi.org/10.1016/j.jnucmat.2009.02.005.

\section{МІКРОСТРУКТУРА ТА ЗМІЦНЕННЯ СТАЛЕЙ Х18Н10Т І Х18Н10Т-ДЗО, ОПРОМІНЕНИХ ІОНАМИ АРГОНУ}

Ігор Колодійа Олексій Великодній ${ }^{a}$, Галина Толмачова ${ }^{a}$, Руслан Василенко $^{a}$, Галина Толстолуцька ${ }^{a}$

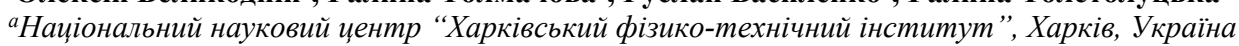
${ }^{b}$ Харківський національний університет імені В.Н. Каразіна, Харків, Украйна

Вивчено зміну мікроструктури і нанотвердості в сталях Х18Н10Т та Х18Н10Т-Д3О після опромінення іонами аргону за допомогою комбінації методів наноіндентування, рентгеноструктурного аналізу, просвічуючої та скануючої електронної мікроскопії. Модифікований ДЗО сплав був отриманий на основі звичайної аустенітної сталі Х18Н10Т шляхом механічного легування сталевого порошку нанооксидами $\mathrm{Y}(\mathrm{Zr})$ з подальшою термо-механічною обробкою. Рентгеноструктурний аналіз не показав суттєвих змін в структурі сталі Х18H10Т після опромінення при кімнатній і підвищених температурах (873 K) і в ДЗО-сталі після опромінення при $873 \mathrm{~K}$, тоді як ознаки подрібнення доменів і появи мікродеформації були виявлені після опромінення сталі Х18Н10Т-ДЗО при кімнатній температурі (КТ). Пошаровий ПЕМ-аналіз проводився для дослідження мікроструктури сплавів вздовж профіля пошкоджень. Більш висока концентрація пошкоджень і Ar явно призводить до збільшення розміру порожнин і їх щільності в обох сталях. Розпухання склало майже половину для Х18Н10Т-Д3О (4,8\%) у порівнянні з Х18Н10Т (9,4\%), що свідчить про поліпшений опір розпуханню в ОД3-сталі. Обговорюється роль границі розподілу оксид/матриця як стоку для радіаційних точкових дефектів і атомів інертного газу. Дрібнодисперсні частки оксиду розглядаються як ефективний фактор в пригніченні укрупнення порожнин і обмеження скупчень дефектів невеликим розміром. Поведінку твердості досліджували як на неопромінених, так і на опромінених зразках і порівнювали 3 такими при кімнатній температурі і підвищеній температурі опромінення. Підвищення твердості неопроміненої ДЗО-сталі в основному пов'язано з подрібненням зерна і додаванням частинок оксиду ітрію. Зміцнення сталі Х18Н10Т-ДЗО після опромінення іонами $\mathrm{Ar}$ при кімнатній температурі виявилося набагато нижче, ніж Х18Н10Т. Для обох сталей в приповерхневій області спостерігаються чорні точки і дислокаційні петлі; однак основний ефект зміцнення обумовлений порожнинами. Було встановлено, що ДЗО-сталь менш схильна до радіаційного зміцнення/окрихчення в порівнянні зі звичайною аустенітною сталлю.

КЛЮЧОВІ СЛОВА: аустенітні сталі, оксидні частинки, опромінення, мікроструктура, порожнини, нанотвердість, розпухання, зміцнення, радіаційна стійкість 